\title{
Internet Financial Reporting Disclosure in the Saudi Listed Manufacturing Companies
}

\author{
Yousef Ali Alwardat ${ }^{1}$ \\ ${ }^{1}$ Accounting Department, Faculty of Economics and Administration, King Abdulaziz University, Jeddah, Saudi \\ Arabia \\ Correspondence: Yousef Ali Alwardat, Accounting Department, Faculty of Economics and Administration, King \\ Abdulaziz University, Jeddah, Saudi Arabia
}

Received: August 21, 2020

Accepted: September 7, 2020

Online Published: September 16, 2020

doi:10.5430/bmr.v9n3p1

URL: https://doi.org/10.5430/bmr.v9n3p1

\begin{abstract}
The broad aim of this study was to measure the extent of Internet Financial Reporting Disclosure (IFRD) in the Saudi Listed Manufacturing Companies (SLMCs). It extends the current literature on IFRD by providing empirical data on Saudi Arabia, a developing country which has been scarcely researched in this field of study. Fifty-three SLMCs were investigated based on an unweighted checklist of 75 items (20 for presentation and 55 for content). The study also employed multi regression analysis to examine the status of IFRD. The analysis revealed an overall level of IFRD of 45 per cent. The study also provided empirical evidence of significant positive associations between IFRD and both company size and profitability. However, no significant positive associations were found between IFRD and company leverage or listed age. The study provides empirical evidence of a moderate IFRD rate. This is likely to motivate Saudi regulatory bodies and administrators of the SLMCs to increase the amount of information they disclose on their websites in order to enhance the transparency of their reports and meet all stakeholder expectations. The findings of this study are exclusive to the SLMCs and do not provide a complete picture about online disclosure by all Saudi listed companies. Therefore, future studies could investigate the status of online disclosure across all Saudi Listed Companies.
\end{abstract}

Keywords: Saudi Arabia, disclosure, corporate reporting, company characteristics

\section{Introduction}

During the past twenty years, the number of internet users worldwide has increased significantly. From 16 million internet users in 1995 (i.e. $46.40 \%$ of the world's total population), the number of internet users around the world on 31 December 2017 had increased to 4,157 million users, representing 54.4\% of the world's total population (Internet World Stats, 2017). Due to this significant increase in internet users, an increasing number of businesses worldwide are using the internet as a means of communication and to carry out tasks such as internet financial reporting (Ettredge et al., 2002; Jones \& Xiao, 2004).

Internet financial reporting disclosure (IFRD) refers to firms using their websites to disseminate financial and nonfinancial information about their performance (Mohamed and Oyelere, 2003, p. 36; Moradi et al., 2011). In comparison to traditional paper-based methods, IFRD is a more cost- and time-effective method of obtaining financial and non-financial information about listed corporations (Ojah \& Mokoteli, 2012; Andrikopoulos et al., 2013). Organizations worldwide are practicing IFRD as user demand for timely data increases (Amin \& Mohamed, 2016). Thus, not only has IFRD become common practice in corporations in developed countries (Pervan, 2006), but it is also being used increasingly by corporations in developing countries (Aly, 2008).

Over the past two decades, IFRD has been widely researched in developed countries, which have well-established accounting information systems. However, research on this topic in developing countries is lacking, despite the continually changing accounting information systems, emerging markets, and continually increasing internet use in these countries (Khadaroo, 2005a; Mohamed et al., 2009; Lymer et al., 1999).

Few studies have explored the use of IFRD in corporations in Saudi Arabia (see for example Hussainey \& Al-Nodel, 2008). The Kingdom's adoption of the 2030 mission, which is expected to have significant impacts on business, 
signifies a need for more research in this area. Thus, the primary aim of this study is to explore the use of IFRD by the Saudi listed manufacturing companies (SLMCs).

There are three main objectives to the current study: to find out about the extent, pattern, and nature of IFRD in the Kingdom and in the SLMCs in particular; to explore the effects of company characteristics like company size, profitability rate, leverage, and listed age on the level of IFRD; and to add to the currently lacking research on IFRD in an emerging economy like Saudi Arabia, thereby benefitting all stakeholders.

The following section explains the importance and motivation of this study; section 3 presents a review of the related literature; section 4 presents the research methodology; section 5 presents the statistical analysis; and, finally, section 6 presents the discussion and conclusion.

\section{Significance and Motivation of the Study}

Saudi Arabia's 2030 mission aims to promote foreign investments and increase investment in the private sector in order to reduce the economy's dependence on oil. Hence, the Saudi Arabian government has issued several legislations to encourage national and international investment. These changes have had a significant impact on the governance of Saudi business, since Saudi markets have entered an era of globalization (www.vision2030.gov.sa). Accounting information systems in Saudi Arabia have also seen significant impact. The Saudi Organisation for Certified Public Accountants (SOCPA) has indicated that transparency in financial reporting plays a significant role in enhancing the level of disclosures in the financial reports of listed companies (www.socba.org.sa).

These significant changes to the Kingdom's accounting information systems have encouraged the researchers of the current study to investigate the level of IFRD in Saudi manufacturing companies, which are a main economic industry in the country. Therefore, by investigating the level of IFRD in the listed manufacturing companies of a country that has an emerging economy and that is undergoing major changes in business management, the present study makes significant contributions to the body of literature on corporate reporting. Furthermore, this study makes the attempt to identify the relevant characteristics of firms which practice IFRD. Finally, the results of the current study are likely to encourage the management teams of the SLMCs to enhance the level of disclosure in their reports by increasing transparency, therefore meeting the expectations of all stakeholders.

\section{Theoretical Background and Literature Review}

The agency theory argues that the separation between shareholders and the management in large companies and the diverging interests between these two parties results in information asymmetry and an increase the agency cost (Jensen $\&$ Meckling, 1976). Hence, management may make more voluntary disclosure via the internet in order to decrease the agency costs arising from these diverging interests (AbuGazaleh et al., 2012; Boubaker et al., 2012) and win stakeholders' trust and support by assuring them that their equity is being properly managed (Marston \& Polei, 2004). In addition, the annual report is a medium through which large companies present their performance to all beneficiaries, which, according to the Signaling Theory, distinguishes one firm from another in terms of the quality and performance (Spence, 1973). Thus, a firm's reputation relies on the amount of information disclosed (AbuGhazaleh et al., 2012). However, whilst it can eliminate the impact of information asymmetry, disclosure is costly (Portes \& Rey, 2000). Therefore, firms should only make voluntary disclosure in cases where the benefits of this disclosure are more significant than its associated costs (Ness \& Mirza, 1991).

Accordingly, managers must decide on the amount of information to be disclosed in annual reports. In recent years, information technology (IT) has allowed firms to report their financial results on the internet, therefore reducing costs and increasing disclosure benefits (Portes \& Rey, 2000) and overcoming the limitations of traditional paper-based disclosure. The internet presents a unique mechanism for communication, due to its ability to provide users worldwide with up-to-date information about companies who are disclosing financial and non-financial information about their affairs (Adams \& Frost, 2004; Beattie \& Pratt, 2001; 2003; Xiao et al., 2002). By making more information available, utilizing audio and video presentations, and establishing a two way dialogue with stakeholders, firms can broaden and segment their disclosure audience, enhance communication quality, and increase disclosure timeliness (Deller et al., 1999; Lymer at al., 1999; Beattie \& Pratt, 2003). Increase in global investments has led to paper-based reporting becoming more expensive and limited in its capacity to reach investors in a timely manner. Meanwhile, internet disclosure is not only faster but also more flexible in formation, cost-effective, and accessible to users on both the national and global levels (Debreceny et al., 2002). Therefore, the benefits of internet disclosure exceed those of printing media such as journals or newspapers (AbuGhazaleh et al., 2012).

IFRD has been widely researched in the past two decades. A large volume of research on this topic has been conducted worldwide and has indicated that internet reporting is a new mechanism of communicating corporate financial 
information to stakeholders. Buzcok et al. (2011) studied the effect that significant regulatory changes to corporate reporting had on internet reporting disclosure in 500 industry firms in Turkey. The study results indicated that IFRD was being practiced by most of these firms and that the number of listed and unlisted firms which practice IFRD had doubled between 2003 to 2010 . Nonetheless, it was found that only six per cent of these firms made voluntary disclosures. Further, the results identified a positive impact of voluntary disclosures on share price, therefore supporting the signaling theory.

Al-Htaybat (2011) explored the IFRD practices of 272 listed companies in Jordan and found that 63 per cent of these firms had their own websites, whilst 70 percent of the firms with websites disclosed information online. The results also showed that firm size, performance, foreign ownership, and familiarity with online reporting could potentially be determining factors of the level of online reporting in Jordan.

Also in Jordan, Momany et al. (2014) investigated the IFRD practices of 127 listed firms in 2008. The results showed 69 per cent of these firms to have accessible websites and an overall average online reporting level of 73 per cent. The results also indicated statistical mismatches between the level of corporate information disclosure on the Amman Stock Exchange (ASE) website and the level of disclosure on the websites of the studied companies. Furthermore, firm size, leverage, age, and ownership concentration were found to be determining factors of the level of online financial reporting by these companies. Finally, in agreement with Momany and Al-Shorman (2006), the study suggested that IFRD practices in the financial sector are more advanced than IFRD practices in the service and industrial sectors.

Using a content analysis approach, a modified version of the disclosure index of Xiao et al. (2004), and a multiple regression analysis, Aly et al. (2010) studied the potential determining factors of corporate internet reporting by firms in Egypt. The study results showed that 56 per cent of the study sample practiced internet reporting to a significant degree. The results also showed that industrial type (financial and communications services), foreign listing, and profitability were the main determining characteristics of how much information was disclosed and how this information was presented on the websites of Egyptian companies. Meanwhile, liquidity, firm size, auditor size, and leverage size were not found to be linked to the degree of corporate internet reporting.

Alsartawi (2018) utilized a checklist consisting of 90 items to measure the level of IFRD and its link to firm performance in the Gulf Cooperation Council (GCC). The results showed a percentage of online financial reporting disclosure in the GCC of 77 per cent, and a positive link between disclosure level and firm performance was identified. However, results varied depending on the different GCC countries and the different industry types. Qatari companies had the highest level of IFRD ( 84 per cent), whilst Bahraini companies had the lowest level (70 per cent). As for the different industry types, banks had the highest level of disclosure (77 per cent), whilst investment companies had the lowest level (75 per cent). Likewise, Alsartawi and Ryad (2019) explored the link between online financial disclosure (OFD) and firm profitability in the context of Islamic banks in GCC countries. The overall level of disclosure by the sampled firms was found to be 72.5 per cent, and OFD and profitability were found to be negatively and insignificantly linked.

In France, a study by Boubaker et al. (2011) examined the role played by firm characteristics on internet corporate reporting. The study examined the levels of internet corporate disclosure using a set of disclosure indexes. The Ordinary Least Square regression framework was also utilized to test the study hypotheses. The results indicated that in French firms, the internet was being used to publish existing information as opposed to timely information. Further, it was found that internet disclosure was more common among large-audited firms, large-sized firms, firms with a dispersed ownership structure, IT firms, and firms with issued bonds or equities. Finally, the results showed that internet disclosure was more suitable for voluntary disclosures than for mandatory disclosures.

In the same vein, Dolinšek et al. (2014) utilized regression analyses and an index containing 32 elements to study the extent to which Slovenian companies carried out internet financial reporting. Further, the study investigated the impact of firm characteristics like size, profitability, ownership, legal form, concentration, industry type, and age on the IFRD index. The results showed that about 53 per cent of large companies used their websites for disclosures, and the factors which were found to impact IFRD were firm size, legal form, ownership concentration, and sector. IFRD was found to be practiced to a greater extent by large firms, public limited companies, financial sector companies, and firms with low ownership concentration.

In the UK, Xiao et al. (2002) examined the determining factors of IFRD. They analysed the perceptions of 20 expert accountants who perceived the internet as a communication system rather than a data processing system. The findings indicated that motivation, demand, lack of standard setting and regulation, and the nature of the internet as a communication system could determine the future of internet reporting. The findings also indicated that the internet could increase the frequency of reporting, widen the range of the information reported, enhance interactivity between 
firms and their users, make financial reporting more cost- and time-effective, increase growth in qualitative and nonfinancial information, and, in some cases, replace traditional reporting methods. However, the study also found that many issues can arise from IFRD, including the increase in non-audit financial and nonfinancial information, the difficulty to regulate reporting, and the overload of information.

In Saudi Arabia, a study by Hussainey and Al-Nodel (2008) explored the level of online corporate governance practice reporting by Saudi listed companies, particularly after the issue of guidance by the Saudi Arabia Capital Market Authority (SACMA). The study utilized a content analysis approach, and a corporate governance disclosure index was therefore developed for the analysis of the contents of each firm's website. According to the study results, most Saudi listed firms were found to use the internet to share information related to corporate governance with their stakeholders. Further, the level of online reporting of corporate governance was found to vary between sectors, whereby the banking sector had the highest level while the industry and service sectors had the lowest level. The study suggested that the factors affecting the level of online corporate governance disclosure by firms in developing countries could include government involvement in the ownership and management of business, the control nature over the sector, and some social assumptions.

\section{Research Methodology}

\subsection{Data}

This study included all of the 53 SLMC listed on the Saudi Stock Market Exchange (SSME) in December 2018. The list of firms was downloaded from the SSME website (https://www.fxnewstoday.ae/arab-markets). Table 1 presents this list with the rate of each type of industry. To find out whether these firms had websites, the SSME home page, as well as the Google search engine, was used. Where corporate websites were available, the search aimed to find out whether these websites had been used to disclose financial and non-financial information about the firm. In order to measure the impact of the independent variables (firm profitability, size, leverage, and listed age) on the dependent variable (IFRD), data was manually collected from the annual reports of the sample firms on December 31 2018. These reports were downloaded from the firms' official websites or from Arqam (https://www.argaam.com/ar/company/financial-pdf/3), a Saudi database. In order to make sure that all the firms had finalized and published their 2018 annual financial reports, data collection took place between January and April 2019.

Table 1. Description of the manufacturing firms according to their type of industry

\begin{tabular}{lll}
\hline Type of industry & Number of firms & Percentage \\
\hline Petrochemical Firms & 14 & $26.42 \%$ \\
Cement Firms & 14 & $26.42 .71 \%$ \\
Agriculture and Food Firms & 13 & $24.52 \%$ \\
Investment manufacturing firms & 12 & $22.64 \%$ \\
\hline
\end{tabular}

To analyse the collected data, a content analysis approach was taken to measure and quantify the level of IFRD in the SLMCs and to determine its association with the different characteristics of manufacturing firms (i.e., firm size, profitability, leverage, and age). A content analysis approach allows for the collection of qualitative data from company websites and the use of quantitative analytical techniques like SPSS software to analyse the data (Abbott \& Monsen, 1979).

\subsection{Measuring the Level of IFRD}

In terms of the disclosure index, Khan and Ismail (2010) have classified disclosure items into content items and presentation items. The authors argued that content items include companies' corporate financial and nonfinancial information, while presentation items are items that can assist users in using the display of this information. The Financial Accounting Standards Board (2000) has also described IFRD items in terms of content and presentation. Content items usually contain voluntary and mandatory disclosure items, including items like financial history, press releases, and stock quotes. Meanwhile, presentation items include quarterly and annual financial reports in different forms, including printed annual reports and dynamic media such as sound and video used to improve information readability, comprehensibility, and display. 
Different studies have been used as key studies for the selection of an appropriate checklist of items that could be applied to measure the level of IFRD in the SLMCs. These studies include Xiao et al. (2004); Guthrie and Abeysekera (2006); Hanafi et al. (2009); Al-Htaybat (2011); Alturki (2004), and Al-Sartawi (2016). After reviewing these studies, the decision was made to adopt the disclosure index used by Al-Sartawi (2016), after making minor modifications in order to reflect the context of Saudi Arabia. This index was found to be appropriate as it has been used to assess the level of financial disclosure in some listed companies in Gulf countries, including Saudi Arabia. Further, it is the most recent index among the aforementioned key studies. To validate the selected index, the researcher compared all the index items with the disclosure items recommended by the Saudi Arabian Capital Market Authority (SACMA). This allowed for the construction of the final disclosure index, which is applicable to the SLMCs.

The checklist used in this study is composed of 75 elements in total, 20 general evaluation elements related to presentation issues and 55 elements related to the content of IFRD. It is expected that these elements represent the status of IFRD by the Saudi Manufacturing Listed Firms. The index is presented in Appendix A. The dichotomous evaluation technique was used to calculate the total scores of items for each firm. If a company website had a specific element, a value of 1 was given; otherwise, a value of 0 was given (Hossain and Hammami, 2009; Al-Htaibat, 2011; Alturki, 2014).

Therefore, for each firm, the variable 'actual online disclosed items' (AODI) represented the total disclosure score, which could take a maximum value of 75 for all firms. The IFRD index was calculated as follows:

$$
\text { IFRD Index }=\sum_{i=1}^{n} \frac{d i}{n}
$$

where:

di: disclosed item $=1$ if the company had disclosed the item, otherwise 0 .

n: maximum score a company could obtain, which is 75 in this study.

\subsection{Research Variables and Hypotheses}

The impact of different firm characteristics on the level of disclosure has been thoroughly examined worldwide. The literature reveals a mixed picture regarding the association between these characteristics and IFRD level. The significance of this association varies between countries and between firms in a country. Although the Kingdom of Saudi Arabia has an emerging market, few studies have explored this issue (see for example: Alsaeed, 2006; Hossain and Hammami, 2009; Alturki, 2014). Therefore, the current study has examined the impact of firm profitability, size, leverage, and age on the level of IFRD in the SLMCs.

\subsubsection{Company Profitability}

Profitability is an important factor that might determine the level of disclosure (Marston and Polei, 2004; Aljifri, 2008; Hossain and Hammami, 2009; Aly et al., 2010; Alturki, 2014; Khalil and O'sullivan, 2017. The agency theory and the signaling theory have both suggested that there is always an agency problem due to the asymmetric information which results from the separation between managers and owners of publicly held companies. Hence, both theories have argued that, in comparison to less profitable companies, highly profitable firms are likely to disclose more information as a signal of their efforts and success (Inchausti, 1997; Dyczkowska, 2014). Return on assets will be used in the current study as a proxy to examine the link between firm profitability and disclosure level. Hence, the following hypothesis has been developed:

H1. There is a positive association between firm profitability and the level of IFRD in the SLMCs.

\subsubsection{Company Size}

The agency theory states that, in comparison to small companies, large companies are likely to incur higher agency costs (Jensen et al., 1976). These agency costs may exist due to the conflict of interests between shareholders and managers; therefore, companies are likely to make increased disclosures in order to reduce these costs (Marston and Polei, 2004). The reviewed studies highlight the role that company size plays in determining the level of disclosures. The majority of studies on this issue have indicated a positive link between the two aforementioned variables (see for example: Belkaoui-Riahi, 2001; Larran \& Giner, 2002; Allam \& Lymer, 2003; Oyelere et al., 2003; Xiao et al., 2004; Bollen et al., 2006; Al-Shammari, 2007; Trabelsi et al., 2008; Damaso and Lourenço, 2011; Al-Htaybat, 2011; Alturki, 2014; and Khalil and O'sullivan, 2017), although some exceptions exist (see Marston, 2003; Agyei-Mensah, 2012). Thus, the present study will use total assets as proxy measures of company size, and it can therefore be hypothesized that: 
H2. There is a positive association between firm size and the level of IFRD in the SLMCs.

\subsubsection{Company Leverage}

The third variable examined in the current study was leverage. Leverage refers to the capital structure of a company. This variable often raises the following question: to what extent does a company rely on debt to finance its assets? The impact of leverage on the level of disclosures has been examined based on the agency theory (Watson et al., 2002; Alsaeed, 2006; Abdullah \& Ku Ismail, 2008). The concerns associated with leverage are the risk implied by the debt and the agency costs a company will be prone to (Alsaeed, 2006). Based on this line of reasoning, a company is likely to make a high level of disclosures in order to decrease these agency costs and the information asymmetries between the company and its creditors (Inchausti, 1997; Uyar \& Kilic, 2012a). The literature reviewed has shown a mixed picture regarding the impact of leverage on the level of disclosure. Scholars such as Ho \& Wong (2001), Aksu \& Kosedag (2006), Alsaeed (2006), Huafang \& Jianguo (2007), and Chau \& Gray (2010) provided empirical evidence for an insignificant link between leverage and disclosure. Meanwhile, Malone et al. (1993), Hossain et al. (1995), and Uyar and Kilic (2013) evidenced a positive significant link between these two variables. Therefore, the following hypothesis was developed:

H3. There is a positive association between leverage and the level of IFRD in the SLMCs.

\subsubsection{Company Age}

The signaling theory explains the link between age and the level of IFRD. As a firm's listed age increases, the level of IFRD is also likely to increase, since older companies are less likely to suffer from their competitive advantages (Al-Shammari, 2007). In addition, younger companies may not be able to meet the high costs of gathering, processing, and disseminating information and may not have a 'track record' to rely on to disclose information (Owusu-Ansah, 1998).

Several previous studies have investigated the association between company age and IFRD level, but the picture shown by these studies was also found to be mixed. While Hossain et al. (2009) and Hossain and Hammami (2009) evidenced a significant positive link between company age and IFRD level, Haniffa and cooke (2002), Haniffa et al. (2002), Alsaeed (2006), Hossain et al. (2006), Uyar and Kilic (2013), and Dolinšek et al. (2014) found otherwise. Therefore, the fourth variable examined in this study was age, based on the following hypothesis:

H4. There is a positive association between listed age and the level of IFRD in the SLMCs.

\subsection{Model Development}

Table 2 explains the dependent and independent variables. The majority of the measurements and the expected relationships are congruent with previous research (Cooke, 1989; Gul and Leung, 2004; and Hossain et al., 2009).

Table 2. Dependent and independent variables

\begin{tabular}{llll}
\hline & Variable & Explanation & Expected signs \\
\hline Dependent Variable & IFRD & 1 if the item is disclosed, and 0 if the item is not disclosed. \\
Independent Variables & Prof. & Measured by the return on assets \\
& Size & Measured by the total assets \\
\hline
\end{tabular}

To investigate the link between the predictor variables and the level of IFRD (predicted variable) in the SLMCs, the following multiple regression was estimated using company profitability, size, leverage, and company age as the independent variables and IFRD as the dependent variable.

\section{IFRD $=\beta 0+\beta 1$ PROF $+\beta 2$ SIZE $+\beta 3 L E V+\beta 4 A G E+e$}

where: IFRD $=$ Internet Financial Reporting Disclosure; $\beta 0=$ The intercept of the regression line and its constant value; $\mathrm{PROF}=$ Profitability; $\mathrm{SIZE}=$ Company Size; $\mathrm{LEV}=$ Leverage; $\mathrm{AGE}=$ Company listing age; and $e=$ Error term.

\section{Analysis}

\subsection{Descriptive Statistics}

The descriptive statistics of the predicted and predictor variables in the current study are presented in Table 3. As mentioned above, the index used in this study consisted of 75 disclosure items in total. The level of IFRD was 
measured by dividing the total score of each company by the total number of disclosure items in the index. The analysis revealed that all of the sampled manufacturing companies used the internet to communicate financial information to stakeholders. However, a significant variation was identified in the levels of IFRD between these firms. The mean, maximum, minimum, and standard deviation of these variables are presented in Table 3. As presented in Table 3, the overall level of average IFRD in Saudi manufacturing firms was found to be about $45 \%$, while the minimum and maximum levels were found to be $14 \%$ and $75 \%$, respectively. In terms of the predictor variables, the table shows a profitability mean of $4 \%$, with a maximum of $21 \%$, a minimum of minus $51 \%$, and a standard deviation of 0.1050 . The mean company size was found to be 13.1 , and the mean leverage was found to be $40 \%$, indicating a moderate level of leverage among the sampled companies. Finally, the mean company age was found to be 32.30 with a standard deviation of 15.7108, while the maximum and minimum ages were 66 and 6 , respectively.

Table 3. Descriptive statistics of the variables

\begin{tabular}{lllllll}
\hline Variables & Indicators & $N$ & Mean & Maximum & Minimum & SD \\
\hline IFRD & IFRD & 53 & 0.45121783 & .7533333 & .14 & 0.175651329 \\
Profitability & Prof. & 53 & 0.042929341 & 0.212092185 & -0.51184671 & 0.104732506 \\
Size & Size & 53 & 13063010464 & $3.16893 \mathrm{E}+11$ & 237179321 & 45189935938 \\
Leverage & Lev. & 53 & 0.403538 & 0.883744 & 0.044453 & 0.221057 \\
Age & Age & 53 & 32.30189 & 66 & 6 & 15.71083 \\
\hline
\end{tabular}

\subsection{Regression Analyses}

Many previous studies have utilized multiple regression analysis to investigate the association between certain company characteristics and IFRD level. Tables $4 \& 5$ present the results of the multiple regression model for the IFRD level in the SLMCs. The value of $\mathrm{R}^{2}$ in table 4 explains about 41 per cent of the variance in the level of IFRD among the sampled companies. The ANOVA analysis in Table 5 shows a positive value of $F(8.25252685)$ and an overall P-value (F test) of 3.05E-06, which is less than the significant level of 0.05 per cent. This indicates that, in general, the multiple regression analysis in this study is significant. In addition, Table 4 shows that two of the predictor variables examined in this study (profitability and company size) determine the level of IFRD in the SLMCs, since the P-value for each of them (3.4390E-05 and 3.4390E-05, respectively) is less than the significant level of 0.05 per cent. This provides empirical support for two hypotheses regarding profitability and company size and suggests that both these variables have a significant positive association with the level of IFRD in the SLMCs. However, this is not the case for the other two predictor variables (leverage and listed age) since the P-value for each of them exceeded the significant level of 0.05 per cent.

Table 4. Regression results

\begin{tabular}{lllllll}
\hline & Coefficients & Standard Error & $t$ Stat & $P$-value & Lower 95\% & Upper 95\% \\
\hline Intercept & 0.336688839 & 0.076168659 & 5.012588355 & $7.72 \mathrm{E}-06$ & 0.201637 & 0.4717405 \\
Profitability & 1.007314222 & 0.220470716 & 4.568925254 & $3.4390 \mathrm{E}-05$ & 0.564028 & 1.4506003 \\
Total assets & $1.3819 \mathrm{E}-12$ & $4.32414 \mathrm{E}-13$ & 3.195791212 & $3.4390 \mathrm{E}-05$ & $5.1247 \mathrm{E}-1$ & $2.2513 \mathrm{E} 12$ \\
Leverage & 0.1480821 & 0.104185555 & 1.421330429 & 0.16168547 & -0.061397 & 0.3575612 \\
Age & -0.00020193 & 0.00126878 & -0.15915617 & 0.87421363 & -0.002753 & 0.0023491 \\
\hline
\end{tabular}

\begin{tabular}{|l|l|}
\hline \multicolumn{2}{|l|}{ Model Summary } \\
\hline Multiple R & 0.638343 \\
\hline R Square & 0.407481 \\
\hline Adjusted R square & 0.358105 \\
\hline Standard Error & 0.140729 \\
\hline Observations & 53 \\
\hline
\end{tabular}


Table 5. ANOVA Analyses

\begin{tabular}{llllll}
\hline & $D f$ & $S S$ & $M S$ & $F$ & Significance $F$ \\
\hline Regression & 4 & 0.653753386 & 0.163438347 & 8.25252685 & $3.7796 \mathrm{E}-05$ \\
Residual & 48 & 0.950622855 & 0.019804643 & & \\
Total & 52 & 1.604376241 & & & \\
\hline
\end{tabular}

\section{Discussion and Conclusion}

This study aimed to investigate the level of IFRD in the SLMCs. The study also investigated the association between some company characteristics (i.e. company profitability, size, leverage, and listed age) and the level of IFRD in the SLMCs. In addition, the study extends the literature on internet corporate disclosure by examining the level of IFRD in Saudi Arabia, a developing country with a growing capital market. Further, Saudi Arabia is undertaking a major reform which places emphasis on boosting investment in the private sector and offering investment opportunities for national and international investors. An unweighted disclosure index was designed for this study. The index consisted of 75 items in total, 20 of them for presentation and 55 for corporate disclosure. The study also tested four hypotheses to examine the association between IFRD level and company profitability, size, leverage, and listed age in the SLMCs.

This study found that the overall average of IFRD among the SLMCs is 45 per cent. Consistent with Alturki (2014), this moderate rate of IFRD can be considered acceptable because the Kingdom has a growing capital market with a weak regulatory environment and weak corporate governance. This, according to Alturki (2014), is more likely to cause a low level of information disclosure. Hence, in order to increase the level of IFRD and therefore minimise agency costs and asymmetric information between listed companies and stakeholders, Saudi regulatory bodies may need to impose more rules on the Saudi Listed Companies (Debreceny et al., 2002). Another possible reason for the moderate rate of disclosure in the SLMCs could be related to the transitional period during which all Saudi listed companies are operating. A major change was imposed on these firms in January 2009, whereby it became a requirement for companies to adopt International Financial Reporting Standards (IFRS). This is likely to have impacted accounting information systems in the Kingdom. These findings might open windows for future studies to examine the impact of applying the IFRS on the level of IFRD in the Saudi Listed Companies.

As for the impact of different company characteristics on the IFRD in the SLMCs, the analysis indicates the presence of a significant positive link between IFRD level and both profitability rate and company size. These results are in line with the signalling theory, indicating that large and more profitable firms are likely to disclose more information as positive signals in order to attract more investors. Also, these findings are consistent with the findings of several published studies on IFRD. Al-Sartawi (2018) measured the level of IFRD and its link to profitability in the Gulf Cooperation Council (GCC) countries and found a positive link between these two variables. Al-Htaybat (2014) examined the level of IFRD in Jordan and the effect of company size and profitability on IFRD level. Based on a sample composed of 175 Jordanian listed companies, the author identified a significant positive impact of company size and profitability on IFRD level. Omran and Ramdhony (2016) explored the extent and determinants of internet corporate reporting by 34 Mauritius stock market exchange listed firms. The results indicated that company size positively and significantly impacted the level of IFRD, whereas no significant link between profitability and the level of IFRD was identified. Aljawder and Sarea (2016) conducted an exploratory study to explore the level of internet corporate reporting in 47 listed companies in Bahrain. The results evidenced a significant positive relationship between firm size and IFRD level. However, Aljawder and Sarea's study contradicts the findings of this current study on profitability rate, since it found no significant positive impact of profitability on online reporting level.

In addition, the findings of this study did not provide empirical evidence of a significant positive relationship between the level of IFRD and company leverage or listed age, since the P-value for each of these predictor variables exceeded the significant value of 0.05 per cent. As for company leverage, the results of this study are in accordance with the results reached by Oxelere et al. (2003), Aly et al. (2010), and Omran and Ramdhony (2016), since none of these studies provided empirical evidence for a significant positive link between IFRD and company leverage. However, profitability was identified by these studies as the main determinant of the level of disclosures. As for age, the findings of this study contradict a study conducted by Al-Shammari (2007), who identified a positive link between the level of internet disclosure and company listed age in Kuwait.

Based on the evidence provided by this study, it can be concluded that although most of the sampled companies have websites, they still do not make sufficient use of these websites to disseminate information about their annual reports 
for decision makers. This is in contrast with the agency theory and is more likely to widen the gap between these companies and their stakeholders. Finally, this study has provided empirical evidence from listed companies in a developing country like Saudi Arabia, therefore contributing to the literature on internet financial reporting disclosure. However, the results of this study are limited to a single Saudi industry, manufacturing companies, and do not provide a full picture of the status quo of IFRD in all Saudi industries. Therefore, future studies could be conducted to investigate the level of disclosure across all Saudi industries.

\section{References}

Bangs, J. (2012). Transforming a business statistics course with just-in-time teaching. American Journal of Business Education, 5(1), 87-94. https://doi.org/10.19030/ajbe.v5i1.6708

Salazar, R. J., \& Wang, J. (2013). The evolution of strategies: multinational subsidiaries operating in china. Journal of Applied Business Research, 29(5), 1261-1280. Retrieved from https://www.cluteinstitute.com/ojs/index.php/JABR/article/view/8012/8066

Abbott, W. F., \& Monsen, R. J. (1979). On the measurement of corporate social responsibility: self-reported disclosures as a method of measuring corporate social environment. Academy of Management Journal, 3, 501-515. https://doi.org/10.1108/1985251088000063222

Abdullah, A., \& Kuismail, K. N. I. (2008). Disclosure of voluntary accounting ratios by Malaysian listed companies. Journal of Financial reporting and Accounting, 6(1). 1020.

AbuGhazaleh, N. M., Qasim, A., \& Roberts, C. (2012). The determinants of web-based investor relations activities by companies operating in emerging economies: the case of Jordan. The Journal of Applied Business Research, 28(2), 209-226. https://doi.org/10.19030/jabr.v28i2.6842

Agyei- Mensah, B. K. (2018). The effect of audit committee effectiveness and audit quality on corporate voluntary disclosure quality. African Journal of Economic and Management Studies. Retrieved from https://doi.org/10.1108/AJEMS-04-2018-0102.

Al-Htaybat, K. (2011). Corporate online reporting in 2010: a case study in Jordan. Journal of Financial Reporting \& Accounting, 9(1), 5-26.

Al Jawder, N. A., \& Sarea, M. A. (2016). Determinations of Internet Financial Reporting: Evidence form Bahrain Bourse. Jordan Journal of Business Administration, 12(4), 935-960. 26.

Aljifri, K. (2008). Annual report disclosure in a developing country: The case of the UAE. Advances in Accounting, 24, 93-100.

Allam, A., \& Lymer, A. (2003). Developments in internet financial reporting: review and analysis across five developed countries. International Journal of Digital Accounting Research, 3(6), 165-206.

Alsaeed, K. (2006). The association between firm-specific characteristics and disclosure: The case of Saudi Arabia. Managerial Auditing Journal, 21(5), 476-496. https://doi.org/10.12691/jfa-5-2-3

Al-Sartawi, A. (2016). Measuring the level of online financial disclosure in the Gulf Cooperation Council Countries. Corporate Ownership and Control, 14(1), 547-558. https://doi.org/10.22495/cocv14i1c4art1

Al-Sartawi, A. M. (2018). Online financial disclosure and firms' performance: Evidence from the Gulf Cooperation Council countries. World Journal of Entrepreneurship, Management and Sustainable Development, 14(2), 178-190. Retrieved from https://doi.org/10.1108/WJEMSD-11-2017-0082.

Al-Sartawi, A., \& Reyad, S. (2019). The Relationship between the Extent of Online Financial Disclosure and Profitability of Islamic Banks. Journal of Financial Reporting and Accounting. Retrieved from https://doi.org/10.1108/JFRA-11-2017-0103.

Al-Shammari, B. (2007). Determinants of internet financial reporting by listed companies on the Kuwait Stock Exchange. Journal of International Business and Economics. Retrieved from http://findarticles.com/p/articles/mi_6775/is_1_7/ai_n28522796/?tag=content;coll.

Alturki, K. H. (2014). Voluntary disclosure by Saudi Companies. Research Journal of Finance and Accounting, $5(20)$.

Aly, D. A. E. (2008). Assessing the development of voluntary internet financial reporting and disclosure in Egypt. $\mathrm{PhD}$ thesis, University of Hull Business School, Hull. \{Google Scholar\} 
Aly, D., Jon, S., \& Hussainey, K. (2010). Determinants of corporate internet reporting: evidence from Egypt. Managerial Auditing Journal, 25(2), 182-202. https://doi.org/10.1108/02686901011008972

Amin, M., \& Mohamad, E. K. (2016). Auditors' perceptions of the impact of continuous auditing on the quality of Internet reported financial information in Egypt. Managerial Auditing Journal, 31(1), 111-132. Retrieved from https://doi.org/10.1108/MAJ-01-2014-0989

Andrikopoulos, A., Merika, A. A., Triantafyllou, A., \& Merikas, A. G. (2013). Internet disclosure and corporate performance: A case study of the international shipping industry. Transportation Research Part A: Policy and Practice, 47, 141-152. Retrieved from https://doi.org/10.1016/j.tra.2012.10.016.

Aksu, M., \& Kosedage, A. (2006). Transparency and disclosure scores and their determinance in the Istanbul Stock Exchange. Corporate Governance, 14(4), 62-77.

Barako, D. G., Hancock, P., \& Izan, H. Y. (2006). Relationship between corporate governance attributes and voluntary disclosures in annual reports: The Kenyan experience. Financial Reporting Regulation and Governance, 5(1), 1-25.

Beattie, V., \& Pratt, K. (2001). Business reporting: Harnessing the Power of the internet for user. ICAS, Edinburgh.

Beattie, V., \& Pratt, K. (2003). Issue concerning web-based business reporting: an analysis of the views of interested parties. The British Accounting Review, 35, 155-187. https://doi.org/10.1016/S0890-8389(03)00016-7

Belkaoui-Riahi A. (2001). Level of multi-nationality, growth opportunities and size as determinants of analysts ratings of corporate disclosures. American Business Review, 19(2), 115-220.

Bollen, L., Hassink, H., \& Bozic, G. (2006). Measuring and explaining the quality of Internet investor relations activities: a multinational empirical analysis. International Journal of Accounting Information System, 7(4), 273-298. https://doi.org/10.1016/j.accinf.2006.04.005

Botosan, C. A. (1997). Disclosure Level and the Cost of Equity Capital. The Accounting Review, 72(3), 323-349. Retrieved from https://www.jstor.org/stable/248475

Boubaker, S., Faten Lakhal, F., \& Nekhili, M. (2012). The determinants of web-based corporate reporting in France. Managerial Auditing Journal, 27(2), 126-155. https://doi.org/10.1108/02686901211189835

Bozcuk, A. E., Aslan, S., \& Burak Arzova, S. (2011). Internet financial reporting in turkey. Euromed Journal of Business, 6(3), 313-323.

Chau, G., \& Gray, S. J. (2010). Family ownership, board independence and voluntary disclosure: evidence from hong kong. Journal of International Accounting Auditing and Taxation, 19(2), 93-109. https://doi.org/10.1016/j.intaccaudtax.2010.07.002.

Cooke, T. E. (1989). Voluntary corporate disclosure by Swedish companies. Journal of International Financial Management \& Accounting, 1(2), 171-195. https://doi.org/10.1111/j.1467-646X.1989.tb00009.x

Debreceny, R., Gray, G. L., \& Rahman, A. (2002). The determinants of internet financial reporting. Journal of Accounting and Public Policy, 21(5), 371-95.

Deller, D., Stubenrath, M., \& Weber, C. (1999). A survey on the use of the Internet for investor relations in the USA, the UK and Germany. European Accounting Review, 8(2), 351-364. https://doi.org/10.1080/09638189933608764

Dolinšek, T., Tominc, P., \& Lutar Skerbinjek, A. (2014). The determinants of internet financial reporting in Slovenia. Online Information Review, 38(7), 842-860. https://doi.org/10.1108/OIR-02-2014-0025

Dolinsek, A. M., \& Mousa, G. A. (2013). The impact of firm characteristics and corporate governance attributes on internet investor relations: evidence from Bahrain. International Journal of Business and Emerging Markets, $5(2), 119-147$.

Dyczkowska, J. (2014). Assessment of quality of internet financial disclosures using a scoring system. A case of Polish stock. Accounting and Management Information Systems, 13(1), 50-81.

Ettredge, M., Richardson, V. J., \& Scholz, S. (2002). Dissemination of information for investors at corporate web sites. Journal of Accounting and Public Policy, 21, 357-69. https://doi.org/10.1016/S0278-4254(02)00066-2

Financial Accounting Standards Board (2000). Business Reporting Research Project: Electronic Distribution of Business Information, FASB, Norwalk, CT. 
Gul, F.A; Leung, S. (2004). Board leadership, outside directors' expertise and voluntary corporate disclosures. Journal of Accounting and Public Policy, 23(5), 351-379. Retrieved from http://dx.doi.org/10.1016/j.jaccpubpol.2004.07.001

Guthrie. J., \& Abeysekera, I. (2006). Content analysis of social, environmental reporting: what is new? Journal of Human Resource Costing and Accounting, 10(2), 114-26. https://doi.org/10.1108/14013380610703120.

Hanafi, S. R. B. M., Kasim, M. A. B., Ibrahim, M. K. B., \& Hancock, D. R. (2009). Business reporting on the internet: development of a disclosure quality index. International Journal of Business and Economics, 8(1), 55-79.

Haniffa, R. M., \& Cooke, T. E. (2002). Culture, corporate governance and disclosure in Malaysian Corporations. Abacus, 38, 317-349. https://doi.org/10.1111/1467-6281.00112

Chau, G. \& Gray, S. (2010). Family ownership, board independence and voluntary disclosure: Evidence from Hong Kong. Journal of International Accounting, Auditing and Taxation, Vol. 19, Issue 2, pp. 93-109. Retrieved from http://dx.doi.org/10.1016/j.intaccaudtax.2010.07.002

Ho, S. S. M., \& Wong, K. S. (2001). A study of the relationship between corporate governance structures and the extent of voluntary disclosure. Journal of International Accounting, Auditing and Taxation, 10(2), 139-156. http://dx.doi.org/10.1016/S1061-9518(01)00041-6

Hossain, M., \& Hammami, H. (2009). Voluntary disclosure in the annual reports of an emerging country: The case of Qatar. Advances in International Accounting, 25, 255-265.

Hossain, M., \& Reaz, M. (2007). Determinants and characteristics of voluntary disclosure by Indian banking companies. Environment Management, 14(5), 274-288. http://dx.doi.org/10.1002/csr.154

Hossain, M., Islam, K., \& Andrew, J. (2006). Corporate social and environmental disclosure in developing countries: evidence from Bangladesh. Retrieved from http://ro.uow.edu.au/commpapers/179

Huafang, X., \& Jianguo, Y. (2007). Ownership structure, board composition and corporate voluntary disclosure: Evidence from listed companies in China. Managerial Auditing Journal, 22(6), 604-619.

Hussainey, K., \& Al-Nodel, A. (2008). Corporate governance online reporting by Saudi listed companies. Research in Accounting in Emerging Economics, 8, 39-64. Retrieved from http://books.emeraldinsight.com/display.asp?K=9781848552524

Inchausti, B. G. (1997). The influence of company characteristics and accounting regulation on information disclosed by Spanish firms. The European Accounting Review, 6(1), 45-68. Retrieved from http://dx.doi.org/10.1080/096381897336863

Jensen, M. C., \& Meckling, W. H. (1976). Theory of the firm: Managerial behavior, agency costs and ownership structure. Journal of Financial Economics, 3(4), 303-360. Retrieved from http://dx.doi.org/10.1016/0304-405X(76)90025-8

Jones, M. J., \& Xiao, J. Z. (2004). Financial reporting on the internet by 2010: a consensus view. Accounting Forum, 28, 237-63. https://doi.org/10.1016/j.accfor.2004.07.002

Khadaroo, M. I. . (2005). Business reporting on the internet in malaysia and singapore: a comparative study. Corporate Communications An International Journal, $10(1), \quad 58-68$. http://dx.doi.org/10.1108/13563280510578204

Khalil, S., \& O'Sullivan, 1. (2017). Corporate social responsibility: Internet social and environmental reporting by banks. Meditari Accountancy Research, 25(3), 414-446. Retrieved from https://doi.org/10.1108/MEDAR-10-2016-0082

Khan, A., \& Ismail, N. A. (2010). A study of the index of internet financial reporting. International Journal of Postgraduate Business, 2(1), 1-23.

Krippendorff, K. (1980). Content analysis: An introduction to its methodology. Beverly Hills, CA: Sage Publications.

Larran, M., \& Giner, B. (2002). The use of internet for corporate reporting by Spanish companies. The International Journal of Digital Accounting Research, 2(3), 53-82. https://doi.org/10.4192/1577-8517-v2 3

Lymer, A., Debreceny, R., Gray, G. L., \& Rahman, A. (1999). Business Reporting on the Internet. International Accounting Standards Committee. 
Malone, D., Fries, C., \& Jones, T. (1993). An empirical investigation of the extent of corporate financial disclosure in the oil and gas industry. Journal of Accounting, Auditing and Finance, 8(3), 249-273. https://doi.org/10.1177\%2F0148558X9300800306

Marston, C. (2003). Financial reporting on the internet by leading Japanese companies. Corporate Communications, 8(1), 23-7. https://doi.org/10.1108/13563280310458894

Marston, C., \& Polei, A. (2004). Corporate reporting on the internet by German companies. International Journal of Accounting Information Systems, 5, 285-311. https://doi.org/10.1016/j.accinf.2004.02.009

Meek, G. K., Roberts, C. B., \& Gray, S. J. (1995). Factors influencing voluntary annual report disclosures by US, UK and Continental European multinational corporations. Journal of International Business Studies, 26(3), $555-72$.

Merve, K., (2016). Online corporate social responsibility (CSR) disclosure in the banking industry: Evidence from Turkey. International Journal of Bank Marketing, 34(4), 550-569. Retrieved from https://doi.org/10.1108/IJBM-04-2015-0060

Mohamed, E., \& Oyelere, P. (2008). A Survey of internet financial reporting in Bahrain. Studies in Business and Economics, 14(1), 31-49.

Mohamed, E., Oyelere, P., \& Al-Busaidi, M. (2009). A survey of internet financial reporting in Oman. International Journal of Emerging Markets, 4(1), 56-71. Retrieved from https://doi.org/10.1108/17468800910931670

Momany, M., \& Al-Shorman, S. (2006). Web-based voluntary financial reporting of Jordanian companies. International Review of Business Research, 2, 127-139.

Momany, M. T., Al-Malkawi, H. N., \& Mahdy, E. A. (2014). Internet financial reporting in an emerging economy: evidence from Jordan. Journal of Accounting in Emerging Economies, 4(2), 158-174. https://doi.org/10.1108/JAEE-04-2012-0015

Moradi, M., Salehi, M., \& Arianpoor, A. (2011). A study of reasons for shortcomings in establishment of internet financial reporting in Iran. African Journal of Business Management, 8, 3312-3321. https://doi.org/10.5897/AJBM10.1447

Ness, K. E., \& Mirza, A. M. (1991). Corporate social disclosure: a note on a test of agency theory. The British Accounting Review, 23(3), 211-217.

Ojah, K., \& Mokoteli, Th. (2012). Internet financial reporting, infrastructures and corporate governance: An international analysis. Review of Development Finance, 2(2), 69-83. Retrieved from https://doi.org/10.1016/j.rdf.2012.04.001

Omran, M. A., \& Ramdhony, D. (2016). Determinants of Internet Financial Reporting in African Markets: The Case of Mauritius. Journal of Developing Area, 50(4), 1-18.

Owusu-Ansah, S. (1998). The impact of corporate attributes on the extent of mandatory disclosure and reporting by listed companies in Zimbabwe. International Journal of Accounting, 33(5), 605-31. https://doi.org/10.1016/S0020-7063(98)90015-2

Oyelere, P., Laswad, F., \& Fisher, R. (2003). Determinants of internet financial reporting by New Zealand companies. Journal of International Financial Management \& Accounting, 14(1), 26-63. https://doi.org/10.1111/1467-646X.00089

Patelli, L., \& Prencipe, A. (2007). The relationship between voluntary disclosure and independent directors in the presence of a dominant shareholder. European Accounting Review, 16(1), 5-33. http://dx.doi.org/10.1080/09638189700000003

Pervan, I. (2006). Voluntary financial reporting on the internet: analysis of the practice of stock-market listed croatian and slovene joint stock companies. Financial theory and practice, 30(1), 1-27.

Portes, R., \& Rey, H. (2000). The determinants of cross-border equity flows: the geography of information. http://dx.doi.org/10.2139/ssrn.237904

Uyar, A., \& Kılıç, M. (2012). The influence of firm characteristics on disclosure of financial ratios in annual reports of Turkish firms listed in the Istanbul Stock Exchange. International Journal of Accounting, Auditing and Performance Evaluation, 8(2), 137-156. http://dx.doi.org/10.1504/IJAAPE.2012.046603 
Uyar, A., Kilic, M., \& Bayyurt, N. (2013). Association between firm characteristics and corporate voluntary disclosure: Evidence from Turkish listed companies. Intangible capital, 9(4), 1080-1112. http://dx.doi.org/10.3926/ic.439

Slack, R., Shrives, P., Rowbottom, N., \& Lymer, A. (2010). Exploring the use and users of narrative reporting in the online annual report. Journal of Applied Accounting Research. https://doi.org/10.1108/09675421011069487

Trabelsi, S., Labelle, R., \& Dumontier, P. (2008). Incremental voluntary disclosure on corporate websites, determinants and consequences. Journal of Contemporary Accounting \& Economics, 4(2), 120-155. https://doi.org/10.1016/S1815-5669(10)70032-1.

Spence, M. (1978). Job market signaling. In Uncertainty in economics (pp. 281-306). Academic Press.

Xiao, J. Z., Yang, H., \& Chow, C. W. (2004). The determinants and characteristics of voluntary Internet-based disclosures by listed Chinese companies. Journal of accounting and public policy, 23(3), 191-225.

Xiao, Z., Jones, M. J., \& Lymer, A. (2002). Immediate trends in Internet reporting. European Accounting Review, 11(2), 245-275. https://doi.org/10.1080/09638180020017087a

\section{Copyrights}

Copyright for this article is retained by the author(s), with first publication rights granted to the journal.

This is an open-access article distributed under the terms and conditions of the Creative Commons Attribution license (http://creativecommons.org/licenses/by/4.0/). 